\title{
IDENTIFIKASI POTENSI LONGSORAN LERENG PADA KUARI BATUGAMPING MENGGUNAKAN ANALISIS KINEMATIKA
}

\author{
Identification of Slope Failure Potency at Limestone Quarry Using \\ Kinematic Analysis
}

\author{
BAGARAJA SIRAIT*, ZULKIFLI PULUNGAN* dan EKO PUJIANTO* \\ Pusat Penelitian dan Pengembangan Teknologi Mineral dan Batubara \\ Jalan Jend. Sudirman 623 Bandung 40211 \\ Telp. (022) 6030483, fax. (022) 6003373 \\ e-mail: bagaraja.sirait@esdm.go.id \\ * Kontributor utama
}

\begin{abstract}
ABSTRAK
Kestabilan lereng adalah faktor penting pada pekerjaan penambangan kuari karena berkaitan dengan keamanan dan keselamatan pekerja dan peralatan. Kestabilan lereng dipengaruhi oleh beberapa faktor di antaranya dimensi lereng, sifat fisik dan mekanik batuan, struktur geologi batuan serta faktor gaya luar yang bekerja pada lereng tersebut. Pada studi ini, kestabilan lereng diprediksi menggunakan analisis kinematika berdasarkan jenis gerakan material lereng, tanpa menganalisis gaya-gaya penyebab material lereng tersebut bergerak, sehingga yang diamati adalah fenomena struktur batuan berupa arah utama bidang diskontinuitas. Tujuannya adalah memprediksi kemungkinan arah dan terjadinya longsoran lereng. Faktor yang diperhitungkan hanya arah bidang diskontinuitas terhadap arah bidang lereng, sudut kemiringan bidang diskontinuitas dan sudut kemiringan bidang lereng. Hasil analisis menunjukkan beberapa lereng berpotensi longsor dengan tipe planar (plane failure) dan baji (wedge failure). Dari 10 lokasi pengukuran yang ditentukan secara acak, diketahui ada 4 lokasi berpotensi longsor planar 4 dan 5 lokasi longsor baji. Dalam hubungannya dengan arah dan kemiringan lereng, potensi tersebut terjadi di 4 lokasi pengukuran, sedangkan di lokasi lainnya diperkirakan aman karena tidak searah dengan bidang lereng. Kekar dan rekahan tidak menunjukkan arah dominan tertentu tetapi terdapat tendensi pada kwadran 2 dan 4.
\end{abstract}

Kata kunci: kestabilan lereng, analisis kinematika, kemungkinan longsoran.

\begin{abstract}
The slope stability is an important factor for a quarry because it is closely related to the security and safety of workers and equipment in mining work. The slope stability is influenced by several factors including the dimensions of the slope, the physical and mechanical properties of the rock, the geological structure of the rock and the external forces acting on the slope. In this study, the slope stability was predicted using kinematics analysis based on the type of material movement of the slope, without analyzing the force causing the slope material to move. The analysis was based only on the observation of the rock structure phenomenon, such as the joint and crack fields. The aim was to predict the possibility of occurrence and the direction of the failure. Therefore the factors taken into account were the direction of the discontinuity plane in the direction of the slope plane, the discontinuity plane and the slope plane inclination angle. The results of the analysis show the types of failures which potentially occurs such as plane and wedges failures. From the measurement of 10 randomly determined locations, the results show that there were 4 potential locations plane failures and 5
\end{abstract}


locations of wedge failures. Concerning the direction and inclination of the slope, it occurred in 4 measurement locations, while in 6 other locations it was estimated to be safe because it was not aligned with the plane of the slope. The joints and cracks did not indicate a certain dominant direction but there was a tendency in quadrants 2 and 4.

Keywords: slope stability, kinematics analysis, failure possibilities.

\section{PENDAHULUAN}

Tambang kuari adalah satu di antara jenis tambang selain mineral dan batubara. Dalam operasi penambangan, kegiatan tambang kuari perlu memerhatikan aspek geoteknik. Kestabilan lereng merupakan isu penting dalam analisis geoteknik. Isu kestabilan lereng kuari telah diteliti dalam beberapa penelitian sebelumnya. Murniati, Purwoko dan Syafrianto (2020) melakukan studi kestabilan lereng pada kuari batuan granodiorit untuk mencari nilai faktor keamanan lereng. Atiiqah dan Heriyadi (2020) melakukan studi kestabilan lereng front IV pit limit pada kuari batukapur. Hidayatullah, Maryanto dan Hirnawan (2018) dalam studinya mempertimbangkan karakteristik geoteknika dari batugamping penyusun lereng kuari di daerah Songgom, Brebes, Jawa Tengah untuk menentukan geometri lereng bukaan tambang. Sismiani (2017) menganalisis kestabilan lereng kuari di daerah Tuban, Jawa Timur dengan mempertimbangkan karakteristik fisik dan mekanik batugamping penyusun lereng dan pengaruhnya terhadap nilai faktor keamanan. Muntaha (2016) dalam studinya tentang kestabilan lereng tambang kuari juga mempertimbangkan karakteristik fisik dan mekanik batukapur penyusun lereng serta faktor kemiringan dan tinggi galian dalam desain geometri lereng untuk mencari nilai faktor keamanan lereng.

Dalam mengkaji kestabilan sebuah lereng, analisis kinematika merupakan salah satu metode untuk mengetahui jenis dan potensi longsoran di lokasi kuari dengan mengamati bidang ketidakmenerusan (diskontinuitas) yang terdapat di lokasi tersebut. Metode analisis kinematik merupakan sebuah upaya mengetahui kestabilan lereng berdasarkan jenis gerakan material lereng tanpa menganalisis gaya penyebab material lereng bergerak (Gurocak, Alemdag dan Zaman,
2008). Untuk memahami potensi longsoran lereng dan faktor keamanannya, data sudut geser dalam dan densitas perlu diketahui. Dalam metode ini, pengaruh struktur geologi berupa bidang perlapisan, kekar, lipatan, rekahan dan patahan akan dianalisis secara seksama. Panduan dalam melakukan analisis geologi struktur diberikan oleh Sukartono (2013) dan Rizqi (2013). Aspek struktur geologi ini sangat memengaruhi tingkat kestabilan lereng batuan (Wyllie dan Mah, 2004; Grelle $d k k ., 2011$; Rusydy dkk., 2016). Dari hasil analisis ini, akan dapat diperkirakan kondisi kestabilan lereng. Apabila lereng diketahui tidak stabil, maka berdasarkan analisis ini akan dapat diprediksi jenis longsoran yang akan terjadi di masa datang.

Penelitian ini dilakukan di lokasi tambang kuari di daerah Bogor. Beberapa titik pengamatan baik di lokasi lereng dari pit eksisting maupun di singkapan batu gamping berada di lokasi pit rencana yang akan ditambang (Gambar 1). Lokasi ini ditentukan berdasarkan rencana perluasan penambangan di kedua lokasi tersebut. Tulisan ini dibuat untuk memberikan informasi mengenai jenis dan potensi longsoran di lokasi tersebut berdasarkan metode kinematik dengan bantuan perangkat lunak berbasis proyeksi stereografis.

\section{METODE}

Hal pertama yang perlu dilakukan dalam penelitian ini adalah pengambilan data lapangan. Identifikasi struktur massa batuan dilakukan dengan metode scan line di sepanjang lereng pada titik pengamatan yang telah ditentukan. Metode ini digunakan dengan membentangkan meteran sepanjang permukaan lereng dan mencatat struktur massa batuan yang melewati garis scanline (Brown, 1981). 




Gambar 1. Lokasi pengukuran potensi longsoran di tambang kuari

Data lain berupa pengukuran orientasi bidang ketidakmenerusan (diskontinuitas) menggunakan kompas geologi. Nilai kualitas inti bor atau Rock Quality Designation (RQD) merupakan parameter berikutnya yang dihitung dalam survei struktur massa batuan. RQD pertama kali dikembangkan tahun 1967 (Deere $d k k$., 1967; Deere dan Deere, 1989), untuk menilai kualitas inti batuan di sebuah lubang bor berdasarkan kerapatan kekarnya. Untuk data bidang diskontinuitas pada sebuah lereng, persamaan yang dibuat oleh Deere $d k k$. (1967) tidak bisa digunakan karena data lubang bor pada saat penelitian ini dilakukan belum tersedia. Perhitungan nilai RQD sebuah lereng menggunakan metode scanline yang diusulkan oleh Priest (1993) menggunakan persamaan (1).

$\mathrm{RQD}=100 \mathrm{e}^{-0,1 \lambda}(0,1 \lambda+1)$

e merupakan nilai distribusi eksponensial negatif sedangkan $\lambda$ merupakan frekuensi bidang diskontinuitas yang terdapat pada sebuah lereng batuan. Perhitungan $\lambda$ dilakukan dengan cara membagi jumlah kekar yang terdapat dalam lereng terhadap panjang scanline pengukuran.

Selanjutnya, spasi bidang diskontinuitas juga perlu dihitung. Perhitungan spasi dilakukan pada masing-masing kekar (joint set) dengan membagi panjang scanline terhadap jumlah kekar pada masing-masing kekar dengan memperhatikan arah kekar, kemiringan kekar, dan arah lereng.

Semua data lapangan berupa struktur massa batuan yang diperoleh selanjutnya diolah dan dianalisis dengan menggunakan proyeksi stereografi yang diperkenalkan oleh Hoek dan Bray (1981); Goodman (1989); dan Hoek (2007). Data lapangan berupa arah dan kemiringan bidang diskontinuitas. Data tersebut akan diplotkan ke dalam proyeksi stereografi untuk selanjutnya dianalisis tingkat kestabilan lereng dan jenis longsoran yang akan terjadi. Proyeksi stereografi sendiri merupakan sebuah metode memproyeksikan kondisi struktur geologi tiga dimensi menjadi bidang datar dua dimensi. Dengan memahami distribusi bidangbidang lemah yang sudah diproyeksikan, akan bisa diketahui sudut relatif sebuah massa batuan dan selanjutnya digunakan untuk tujuan analisis kinematik. Metode proyeksi stereografi ini biasanya digunakan untuk menganalisis kestabilan lereng dan terowongan (Lee dan Wang, 2011). Berdasarkan proyeksi stereografi, Hoek dan Bray (1981) serta Goodman (1989) membagi 4 jenis longsoran lereng (slope failure) yang mungkin terjadi yaitu: 1). jenis bidang/ planar; 2). longsoran jenis baji (wedge); 3). longsoran jenis gulingan (toppling); 4). longsoran jenis rotasional. Tulisan ini hanya membahas potensi kegagalan/longsoran lereng pada batuan. Keempat jenis longsoran lereng pada batuan beserta pola proyeksi stereografi, dapat dilihat pada Gambar 2. 




Gambar 2. Tipe potensi longsoran lereng di batuan berdasarkan proyeksi stereografi; a). Longsoran jenis rotasional; b). Longsoran jenis planar; c). Longsoran jenis baji;

d). Longsoran jenis gulingan (Hoek dan Bray, 1981; Hoek, 2007)

Wyllie dan Mah (2004) mencatat bahwa longsoran jenis planar terjadi ketika ada blok batuan yang meluncur keluar dari muka lereng. Longsoran jenis ini dapat terjadi bila arah bidang planar minimal $\pm 20^{\circ}$ dari arah lereng, sudut kemiringan lereng $\left(\beta_{\mathrm{s}}\right)$ harus lebih besar dari sudut kemiringan bidang planar $\left(\beta_{\mathrm{j}}\right)$, dan sudut kemiringan bidang $\left(\beta_{\mathrm{j}}\right)$ harus lebih besar dari sudut geser dalam $(\phi)$ batuan pembentuk lereng sebagaimana tersaji pada Gambar 2b. Longsoran jenis baji akan terjadi apabila dua buah bidang rekahan batuan saling berpotongan satu sama lain sebagaimana ditunjukkan pada Gambar 2c. Kemiringan bidang plunge $\left(\beta_{i}\right)$ dihasilkan dari bidang yang saling berpotongan harus lebih landai dibandingkan dengan kemiringan lereng $\left(\beta_{\mathrm{s}}\right)$ akan tetapi kemiringan bidang plunge tersebut harus lebih besar dari sudut geser dalam $(\phi)$. Longsoran jenis gulingan terjadi apabila longsoran jenis ini melibatkan perputaran blok batuan yang memiliki arah rekahan berlawanan arah dengan arah lereng. Proyeksi stereografi dan bentuk longsorannya dapat dilihat pada Gambar 2d. Longsoran jenis gulingan pertama kali diperkenalkan oleh Muller pada tahun 1968 (dalam Bieniawski, 1976; Wyllie dan Mah, 2004). Apabila tingkat pelapukan sangat tinggi dan banyak bidang diskontinuitas, longsoran jenis rotasional akan terjadi sebagaimana ditunjukkan pada Gambar 2a.

\section{GEOLOGI}

Di beberapa lokasi kuari batugamping, satuan geologi penyusun batuan sangat bervariasi.
Wijaya, Karnawati dan Srijono (2015) mencatat bahwa tambang kuari batugamping di Blok Sawir Daerah Tuban, Jawa Timur berada dalam Formasi Paciran yang merupakan kawasan perbukitan kars yang terbentuk oleh endapan aluvial terdiri dari lanau dan lempung berwarna coklat kekuningan dan satuan batugamping terumbu. Selain itu, Wijaya dan Isnawan (2015) juga mencatat bahwa tambang kuari batugamping Gunung Sudo di Desa Karangasem, Gunung Kidul, Yogyakarta berada dalam Formasi Wonosari yang berumur Meosen Tengah Meosen Akhir. Batuan penyusun formasi ini terdiri dari batugamping, batugamping napalan-tufan, batugamping konglomerat, batupasir tufan dan batulanau. Abadi, Idrus dan Irawan (2018) mencatat bahwa tambang kuari batugamping di daerah Karang Dawa, Tegal, Jawa Tengah berada pada Anggota Batugamping Formasi Tapak dan Endapan Lahar Gunung Slamet. Anggota Batugamping Formasi Tapak tersusun atas lensa-lensa batugamping tak berlapis yang berwarna kelabu kekuningan dan berumur sekitar antara Pliosen Awal - Miosen Akhir sedangkan Endapan Lahar Gunung Slamet terdiri dari lahar dengan bongkahan batuan gunung api bersusunan andesit-basal, bergaris tengah 10$50 \mathrm{~cm}$ yang tersebar meliputi daerah datar serta berumur Holosen.

Secara umum, litologi batuan di lokasi penelitian didominasi oleh batugamping dan endapan kwarter (Gambar 3). Merujuk pada peta geologi regional Lembar Bogor (Effendi, 
Kusnama dan Hermanto, 1998) dan Lembar Jakarta dan Kepulauan Seribu (Turkandi, 1992), urutan batuan yang menyusun daerah penelitian dari tua ke muda adalah sebagai berikut:

- Formasi Jatiluhur (Tmj/Mdm) merupakan batuan paling tua diperkirakan berumur Miosen Awal - Miosen Tengah, terdiri dari napal dan batulempung dengan sisipan batupasir gampingan. Bagian atas formasi ini menjemari dengan Formasi Klapanunggal.

- Formasi Klapanunggal (Tmk) diperkirakan berumur Miosen Awal - Miosen Tengah, terdiri dari batugamping koral, sisipan batugamping pasiran, napal, batupasir kuarsa glakonitan hijau. Formasi ini menjemari dengan Formasi Jatiluhur. Ketebalan formasi ini mencapai 500 meter.

- Basal Gunung Dago (Tmpb) diperkirakan berumur Miosen Akhir - Pliosen, terdiri dari basal piroksen yang lapuk dan terkekarkan.

- Formasi Serpong (Tpss) berumur Pliosen terdiri dari perselingan konglomerat, batupasir, batulanau dan batulempung dengan sisa tanaman, konglomerat batuapung dan tuf batuapung.

- Kipas Alluvium (Qav) terdiri dari tuf halus berlapis, tuf pasiran, berselingan dengan tuf konglomeratan.

- Endapan Alluvium (Qa) terdiri dari lanau, lempung, pasir, kerikil, kerakal dan bongkah.

Deformasi yang terjadi di Pulau Jawa pada akhir Kala Miosen Akhir sangat berperan dalam pembentukan struktur geologi di daerah Cileungsi dan sekitarnya. Hal tersebut dibuktikan oleh terdeformasinya semua satuan batuan yang tersingkap di daerah penelitian yang berumur Awal Miosen Tengah-Awal Miosen Akhir. Struktur geologi yang umumnya berkembang antara lain berupa sesar naik dan lipatan yang berarah barat-timur, serta sesar mendatar yang berarah baratlaut-tenggara dan baratdaya-timurlaut. Pola tersebut mengindikasikan bahwa deformasi yang terjadi akibat dari tegasan yang berarah utara-selatan yang identik dengan arah subduksi Jawa (Rosanawita, 2010).

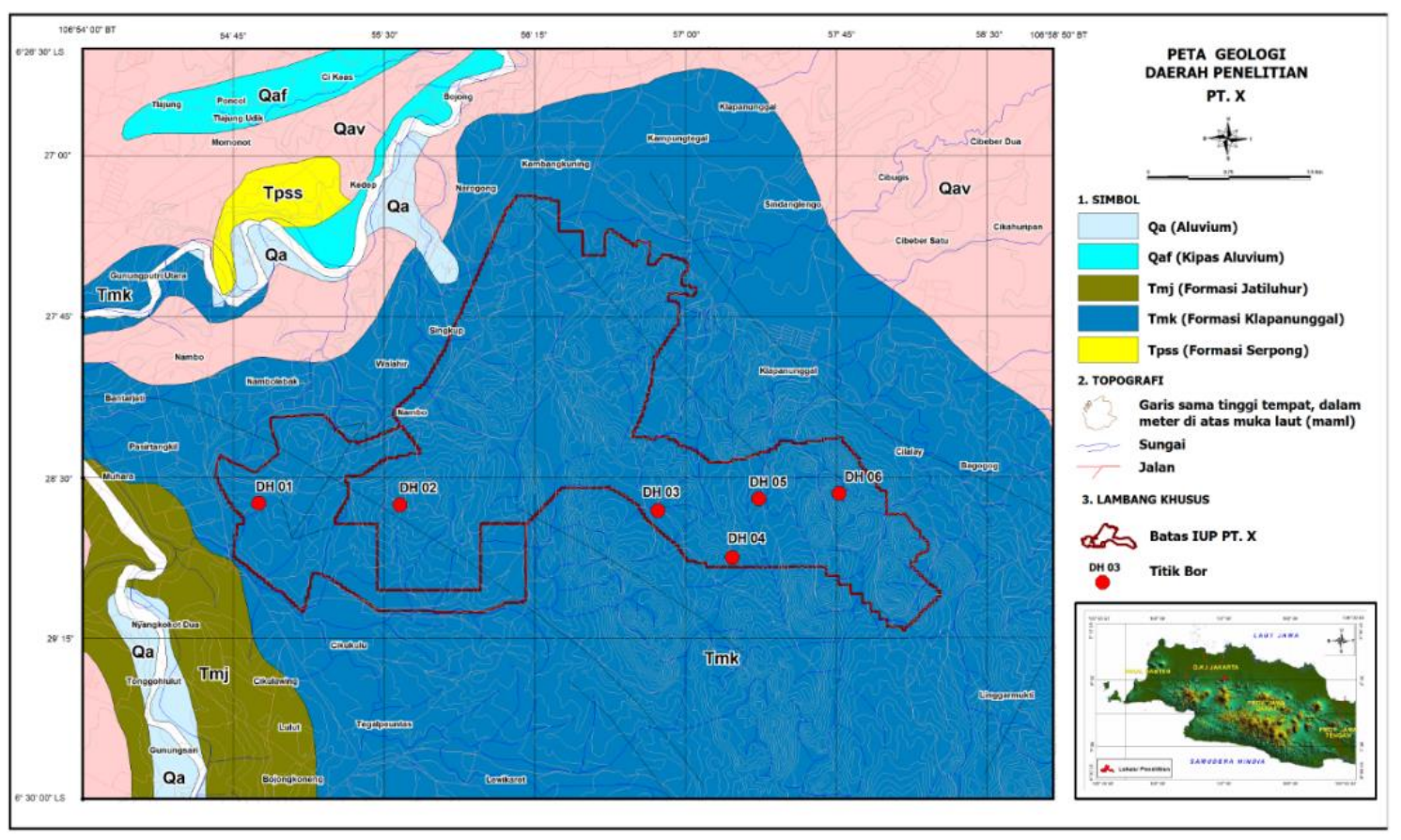

Gambar 3. Geologi daerah penelitian (modifikasi dari Effendi, Kusnama dan Hermanto (1998) dan Turkandi (1992)) 


\section{HASIL DAN PEMBAHASAN}

\section{Hasil}

Sejumlah titik pengukuran (Gambar 1) ditentukan untuk mencatat beberapa informasi penting seperti:

1. Struktur kekar, baik secara statistik (diagram kipas) maupun secara stereografis untuk mengetahui arah utama kekar yang selanjutnya dianggap sebagai arah utama bidang lemah atau bidang diskontinuitas.

2. Kemungkinan arah pergerakan batuan apabila terjadi longsoran

3. Jenis-jenis longsoran yang mungkin terjadi yaitu longsoran tipe bidang (plane failure), tipe baji (wedge failure) dan tipe guling (toppling)

Di dalam areal lokasi penelitian dilakukan pengukuran data struktur minor yang berupa crack dan joint di 10 lokasi pengukuran di dalam area kuari batugamping aktif maupun di area di luar kuari aktif tetapi yang akan segera dibuka menjadi kuari untuk menambah produksi. Tabulasi stasiun pengukuran dan koordinatnya dapat dilihat pada Tabel 1.

Hasil pengamatan di lapangan menunjukkan bahwa spacing antara kekar berkisar kurang dari 0,01 $\mathrm{m}$ hingga mencapai 0,25-2 m. Kekar cenderung tertutup sehingga tidak terdapat material pengisi kekar. Kondisi air di setiap stasiun pengukuran bervariasi kering hingga basah. Tingkat kekuatan batuan tergolong weak rock hingga strong rock. Singkapan batugamping di lereng setinggi 5-10 meter. Pengukuran kelerengan singkapan sebenarnya di lapangan menunjukkan nilai $60-85^{\circ}$.

Tabel 2 memberikan informasi mengenai jenis dan tipe longsoran serta orientasi kekar di beberapa lokasi pengamatan yang ditentukan sebelumnya.

Tabel 1. Tabulasi stasiun dan koordinat pengukuran

\begin{tabular}{clccc}
\hline \multirow{2}{*}{ No. } & Nama Stasiun & \multicolumn{2}{c}{ Koordinat } & Elevasi \\
\cline { 3 - 4 } & Pengukuran & $\mathrm{X}$ & $\mathrm{Y}$ & $(\mathrm{m})$ \\
\hline 1. & ST01_a1 & 71A.B62 & $9.2 \mathrm{XY} .783$ & 115 \\
2. & ST02 & 71A.B16 & $9.2 \mathrm{XY} .069$ & 115 \\
3. & ST02ST3 & 71A.B52 & $9.2 \mathrm{XY} .069$ & 115 \\
4. & ST03 & 71A.B20 & $9.2 \mathrm{XY} .258$ & 113 \\
5. & ST03d & 71A.B74 & $9.2 \mathrm{XY} .258$ & 114 \\
6. & OC05 & 71A.B34 & $9.2 \mathrm{XY} .088$ & 214 \\
7. & OC06 & 71A.B77 & $9.2 \mathrm{XY} .687$ & 145 \\
8. & OC07 & 71A.B23 & $9.2 \mathrm{XY} .374$ & 210 \\
9. & OC08 & 71A.B95 & $9.2 \mathrm{XY} .683$ & 140 \\
10. & OC09 & 71A.B14 & $9.2 \mathrm{XY} .511$ & 152 \\
\hline
\end{tabular}

Tabel 2. Jenis dan tipe serta orientasi struktur di lokasi pengamatan

\begin{tabular}{cccccc}
\hline \multirow{2}{*}{ No. } & Nama Stasiun & \multicolumn{2}{c}{ Orientasi Kekar $($ Crack) } & Jumlah Data & \multirow{2}{*}{ Jenis Struktur } \\
\cline { 3 - 4 } & Pengukuran & Dip/Dip Direction & Strike/Dip & $(10)$ & \\
\hline 1 & ST01_a1 & $65 / 114$ & $(24 / 65)$ & 45 & Batuan masif \\
2 & ST02 & $77 / 53$ & $(323 / 77)$ & 29 & Longsoran baji \\
3 & ST02ST3 & $74 / 65$ & $335 / 74$ & 22 & Longsoran baji \\
4 & ST03 & $67 / 211$ & $121 / 67$ & 37 & Longsoran baji \\
5 & ST03d & $67 / 211$ & $121 / 67$ & 64 & Longsoran baji \\
6 & OC05 & $84 / 21$ & $291 / 84$ & 34 & Longsoran bidang \\
7 & OC06 & $79 / 159$ & $69 / 79$ & 43 & Longsoran bidang \\
8 & OC07 & $82 / 100$ & $10 / 82$ & 50 & Longsoran bidang \\
9 & OC08 & $79 / 90$ & $360 / 79$ & 45 & Longsoran bidang \\
10 & OC09 & $76 / 72$ & $342 / 76$ & 54 & Longsoran bidang \\
\hline
\end{tabular}




\section{Pembahasan}

Sebelumnya, Jariah dkk. (2019), melakukan penelitian sejenis untuk menentukan arah tegangan pembentuk kekar dengan menggunakan diagram rosette. Utama $d k k$. (2014) juga melakukan penelitian dengan metode kinematika untuk analisis kestabilan lereng batu pasir di formasi Butak. Wibowo (2016) dalam penelitiannya melakukan survey batuan dan struktur geologi di lokasi kuari batu andesit di daerah Kulon Progo, Yogyakarta. Nurachman, Najib dan Trisnawati (2017) melakukan analisis kinematika di dalam untuk kestabilan lereng pada kuari batugamping di PT. Semen Indonesia (Tbk) di daerah Tuban, Jawa Timur. Sophian $d k k$. (2019) melakukan analisis kinematika pada lereng batugamping yang terdapat di dalam kampus lapangan PPSDM Geominerba di daerah Padalarang, Jawa Barat. Idris dkk. (2019), melakukan analisis kinematika untuk mengetahui karakteristik kestabilan lereng yang ada di daerah Jatigede Kabupaten Sumedang, Jawa Barat. Murniati, Purwoko dan Syafrianto (2020) menggunakan analisis proyeksi stereografi/stereonet untuk mengetahui kestabilan lereng pada kuari batuan granodiorit di PT. Total Optima Prakarsa.

Penentuan tipe longsoran yang berpotensi terjadi di lokasi pengamatan menggunakan perangkat lunak berbasis analisis stereografis, didasarkan pada persebaran titik - titik pengeplotan, dihubungkan dengan metode pembuatan kontur (contouring). Tipe longsoran yang berpotensi terjadi adalah tipe longsoran planar (plane failure) dan tipe longsoran baji (wedge failure). Tipe longsoran planar didasarkan konsentrasi titik yang terkumpul pada satu daerah tertentu dan tidak berhadapan dengan nilai muka longsoran yang berbentuk setengah lingkaran pada analisis stereografis. Tipe longsoran baji (wedge failure) didasarkan konsentrasi titik yang terkumpul pada dua kutub yang saling berdekatan dan tidak berhadapan dengan nilai muka longsoran.

Pembahasan terhadap hasil pengukuran strike/dip, struktur minor kekar dan fracture di 10 lokasi di dalam quarry aktif maupun di area di luar quarry aktif (di dalam area IUP tetapi belum dilakukan penambangan) adalah sebagai berikut:

\section{Titik Pengamatan ST01_a1}

Batuan pembentuk - lereng berdasarkan pengukuran orientasi titik ST01_a1 di lapangan adalah batugamping (limestone) yang kompak sehingga tidak dijumpai crack maupun joint. Arah dan kemiringan lereng titik ST01_a1 adalah $\mathrm{N} 235^{\circ} \mathrm{E} / 58$. Batugamping di lokasi pengamatan stabil sehingga tidak berpotensi terjadi longsoran planar (plane failure). Interpretasi adanya potensi longsoran tipe planar didasarkan pada beberapa data kekar yaitu berarah N24ํㅡㄴ 65 (Gambar 4). Meskipun demikian, karena arah kemiringan bidang kekar berlawanan dengan arah bidang lereng maka tidak terdapat potensi terjadinya longsor.

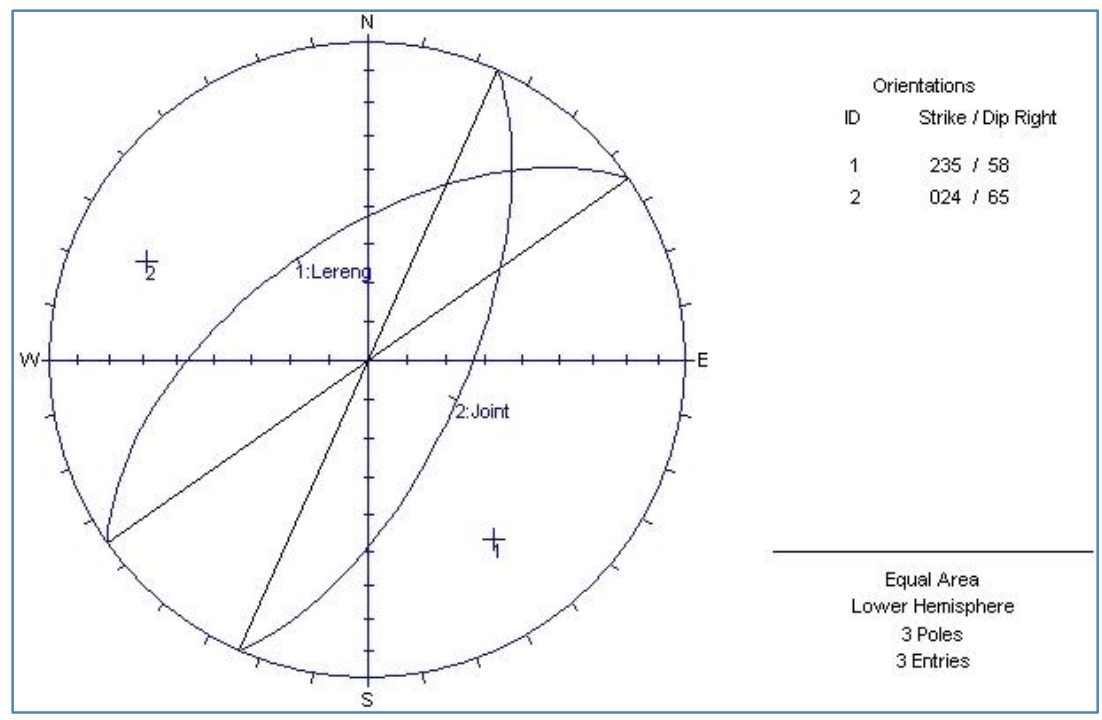

Gambar 4. Analisis stereonet ST01_a1 


\section{Titik Pengamatan ST02}

Strike/dip perlapisan batuan berdasarkan pengukuran orientasi di lapangan titik ST02 adalah $\mathrm{N} 338^{\circ} \mathrm{E} / 77^{\circ}$ dan $\mathrm{N} 295^{\circ} \mathrm{E} / 78^{\circ}$. Tipe longsoran yang berpotensi terjadi adalah tipe longsoran baji (wedge failure). Interpretasi adanya potensi longsoran tipe baji dapat didasarkan pada keberadaan perpotongan arah orientasi utama bidang lemah minor (joint set), yaitu pada kekar 1 dan kekar 2 yang ditunjukkan oleh garis dengan orientasi plunge/trend yaitu $77^{\circ} / \mathrm{N} 53^{\circ} \mathrm{E}$ (Gambar 5). Bidang lemah saling bersudut tajam $\left(77^{\circ}\right)$ lebih kecil dibandingkan kemiringan lereng $\left(80^{\circ}\right)$ sehingga berpotensi terjadinya longsor.

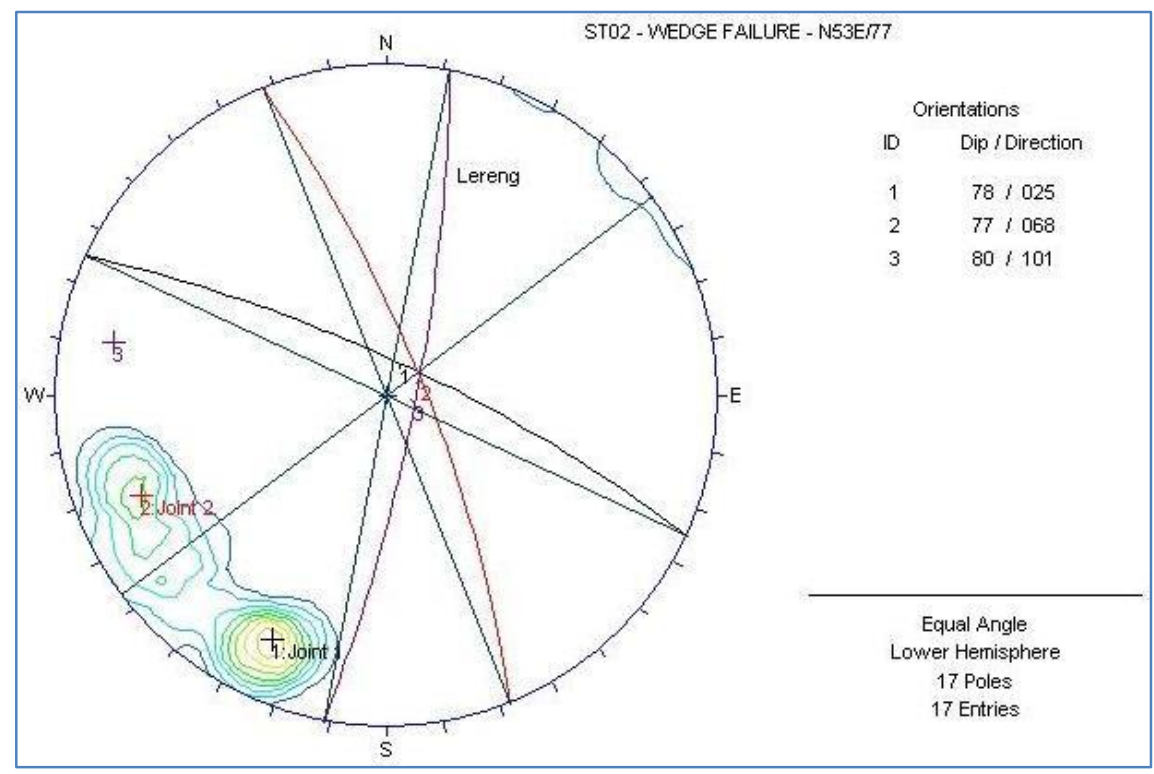

Gambar 5. Analisis stereonet ST02

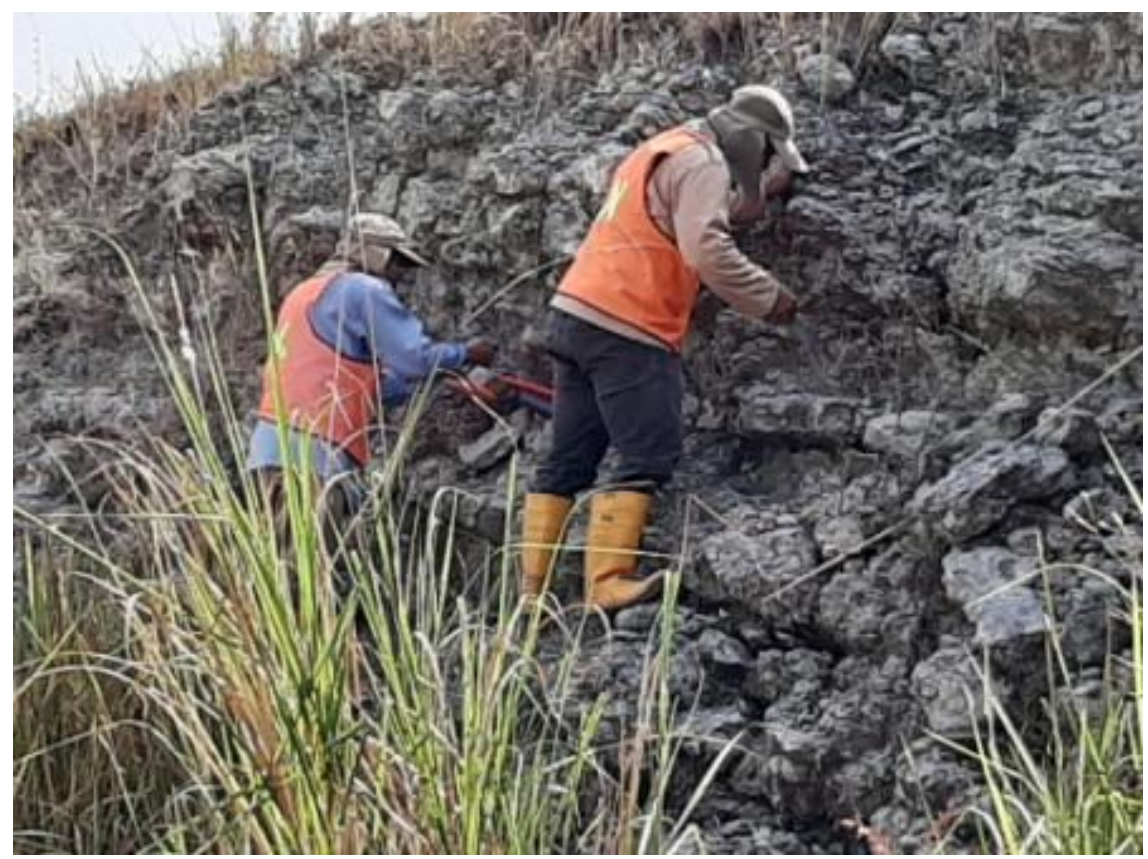

Gambar 6. Kegiatan pengukuran stuktur minor batuan di ST02 


\section{Titik Pengamatan ST02ST03}

Orientasi kekar yang merupakan bidang lemah batuan berdasarkan pengukuran orientasi di lapangan titik ST02ST03 adalah N298 ${ }^{\circ}$ E $77^{\circ}$ dan $\mathrm{N} 340^{\circ} \mathrm{E} / 74^{\circ}$. Karena ada perpotongan antara dua bidang kekar maka tipe longsoran yang berpotensi terjadi adalah tipe longsoran baji (wedge failure). Interpretasi adanya potensi longsoran tipe baji didasarkan pada beberapa data kekar, sumbu baji yaitu berarah $\mathrm{N} 65^{\circ} \mathrm{E} / 74^{\circ}$ (Gambar 7). Bidang lemah saling bersudut tajam $\left(74^{\circ}\right)$ lebih kecil dibandingkan kemiringan lereng $\left(79^{\circ}\right)$ sehingga berpotensi terjadi longsor pada lereng tersebut.

\section{Titik Pengamatan ST03}

Orientasi kekar yang merupakan bidang lemah batuan berdasarkan pengukuran orientasi di lapangan titik ST03 adalah $\mathrm{N} 87^{\circ} \mathrm{E} / 70^{\circ}$ dan $\mathrm{N} 168^{\circ} \mathrm{E} / 73^{\circ}$. Karena ada perpotongan antara dua bidang kekar maka tipe longsoran yang berpotensi terjadi adalah tipe longsoran baji (wedge failure). Interpretasi adanya potensi longsoran tipe baji didasarkan pada beberapa data kekar, sumbu baji yaitu berarah $\mathrm{N} 211^{\circ} \mathrm{E} / 67^{\circ}$ (Gambar 8). Bidang lemah saling bersudut $67^{\circ}$ lebih kecil daripada sudut lereng $\left(79^{\circ}\right)$ sehingga potensi keterjadian longsor pada lereng termasuk tinggi.

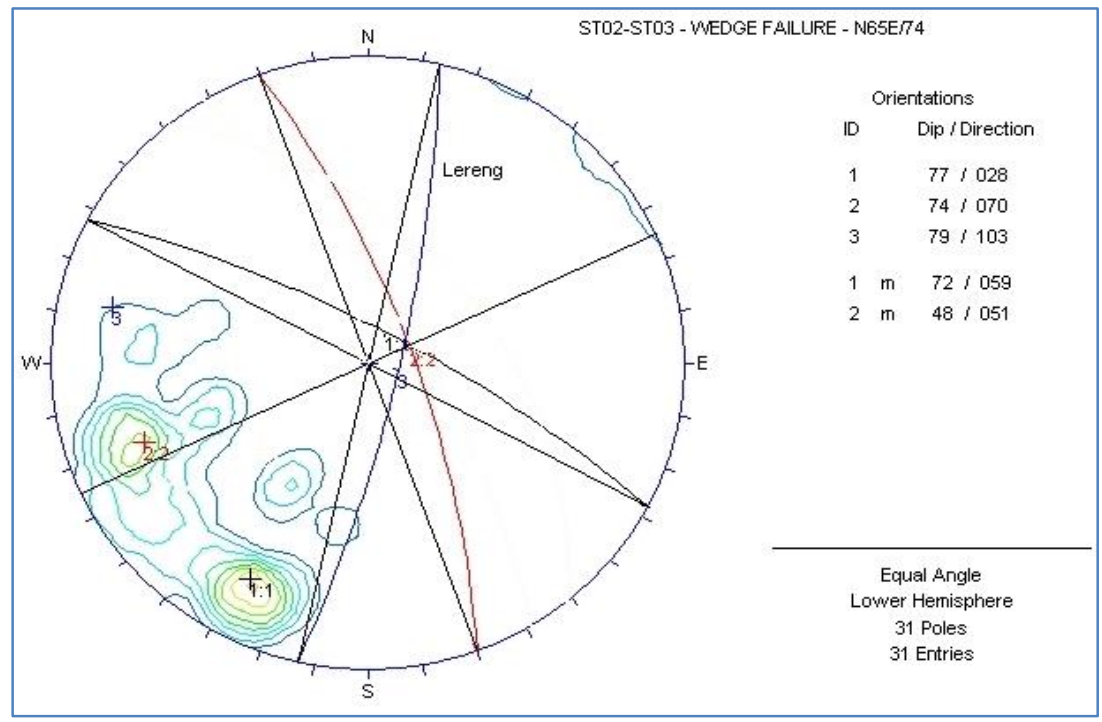

Gambar 7. Analisis stereonet ST02ST03



Gambar 8. Analisis stereonet ST03 


\section{Titik Pengamatan ST03d}

Orientasi kekar yang merupakan bidang lemah batuan berdasarkan pengukuran orientasi di lapangan titik ST03d adalah $\mathrm{N} 86^{\circ} \mathrm{E} / 71^{\circ}$ dan $\mathrm{N} 172^{\circ} \mathrm{E} / 76^{\circ}$. Karena ada perpotongan antara dua bidang kekar maka tipe longsoran yang berpotensi terjadi adalah tipe longsoran baji (wedge failure). Interpretasi adanya potensi longsoran tipe baji didasarkan pada beberapa data kekar, sumbu baji yaitu berarah $\mathrm{N} 211^{\circ} \mathrm{E} / 67^{\circ}$ (Gambar 9). Bidang lemah saling bersudut $67^{\circ}$ lebih kecil dibandingkan sudut lereng $\left(72^{\circ}\right)$ dan juga hampir searah dengan kemiringan lereng sehingga berpotensi terjadinya longsor pada lereng.

\section{Titik Pengamatan OC5}

Arah utama strike/dip joint dan crack batuan di titik OC05 berdasarkan pengukuran orientasi di lapangan adalah mayoritas satu arah $\mathrm{N} 291^{\circ} \mathrm{E} / 84^{\circ}$ sehingga tipe longsoran yang berpotensi terjadi adalah tipe longsoran bidang (plane failure). Interpretasi adanya potensi longsoran bidang dapat didasarkan pada keberadaan arah orientasi utama bidang lemah minor (joint set), yaitu pada kekar dan crack. Kemiringan bidang gelincir sangat tajam $\left(84^{\circ}\right)$ melebihi kemiringan rata-rata lereng $\left(70^{\circ}\right)$ sehingga potensi terjadinya longsor rendah (Gambar 10).

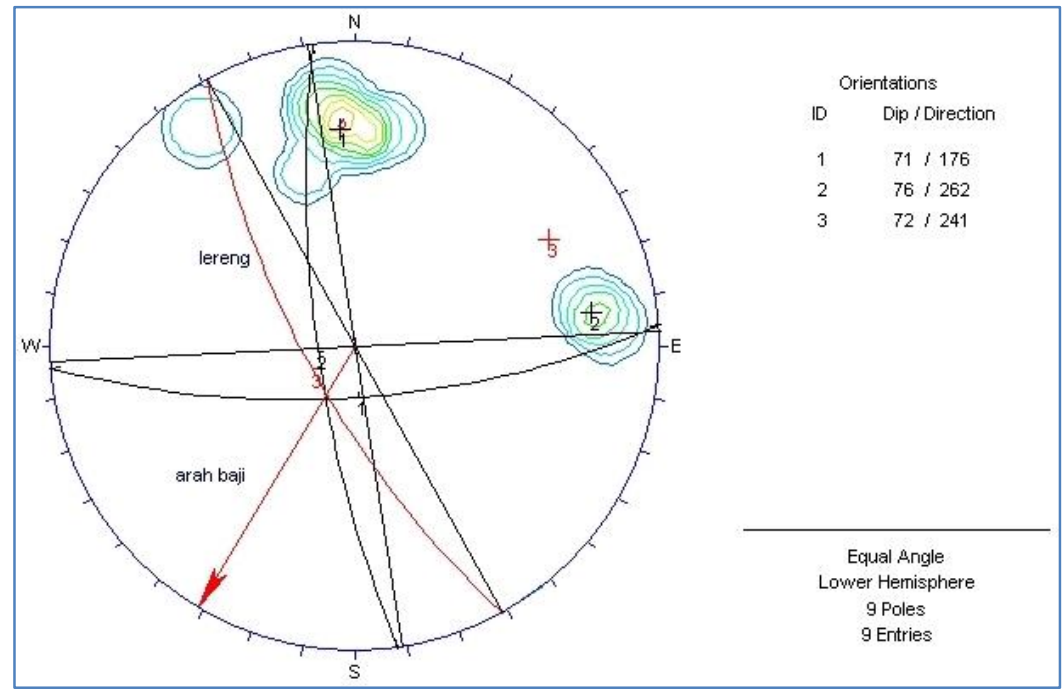

Gambar 9. Analisis stereonet ST03d

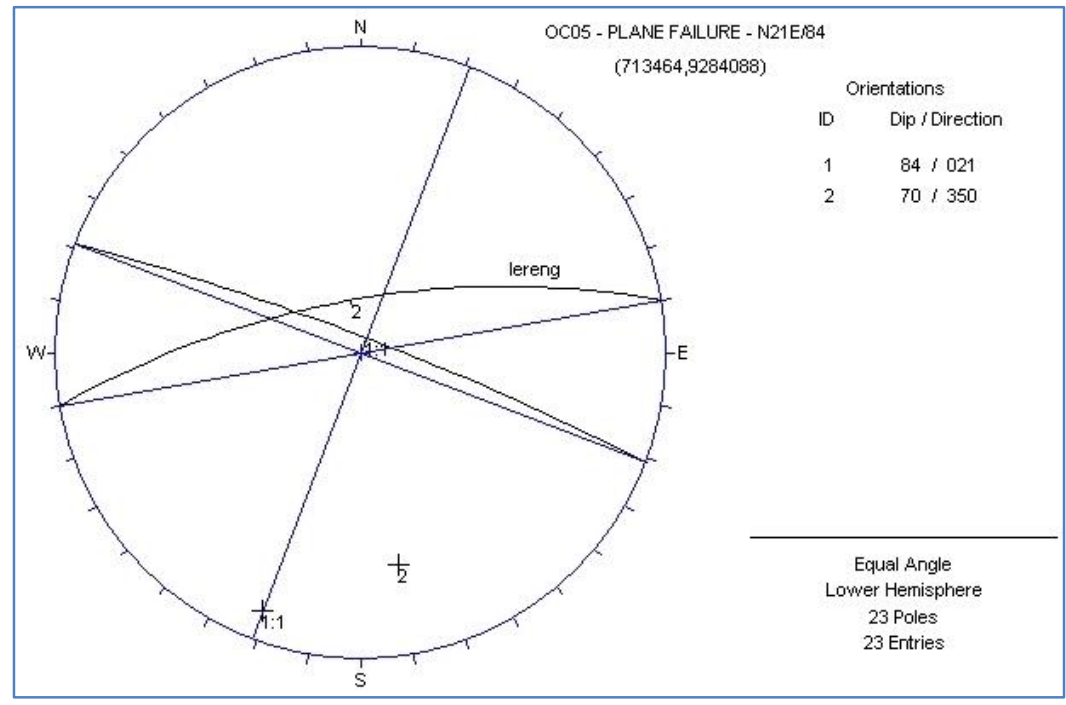

Gambar 10. Analisis stereonet OC5 


\section{Titik Pengamatan OC6}

Arah utama strike/dip perlapisan batuan di titik OC06 berdasarkan pengukuran orientasi kekar dan crack di lapangan adalah dominan satu arah $\mathrm{N} 69^{\circ} \mathrm{E} / 79^{\circ}$ maka tipe longsoran yang berpotensi terjadi adalah tipe longsoran planar (plane failure). Interpretasi adanya potensi longsoran tipe planar didasarkan pada beberapa data kekar dan crack (Gambar 11). Meskipun bidang perlapisan hampir searah dengan bidang lereng tetapi karena lebih besar dibanding kemiringan lereng $\left(72^{\circ}\right)$ maka kecil kemungkinan adanya potensi longsor.

\section{Titik Pengamatan OC7}

Strike/dip perlapisan pada batuan titik OC07 berdasarkan pengukuran orientasi di lapangan adalah dominan pada arah $\mathrm{N} 10^{\circ} \mathrm{E} / 82^{\circ}$ sehingga tipe longsoran yang berpotensi terjadi adalah tipe longsoran bidang (plane failure). Interpretasi adanya potensi longsoran tipe bidang dapat didasarkan pada keberadaan arah orientasi utama bidang lemah minor (joint set), dengan orientasi garis plunge/trend yaitu $82^{\circ} / \mathrm{N} 100^{\circ} \mathrm{E}$ (Gambar 12). Sudut kemiringan bidang lemah lebih besar sehingga potensi keterjadian longsor rendah.

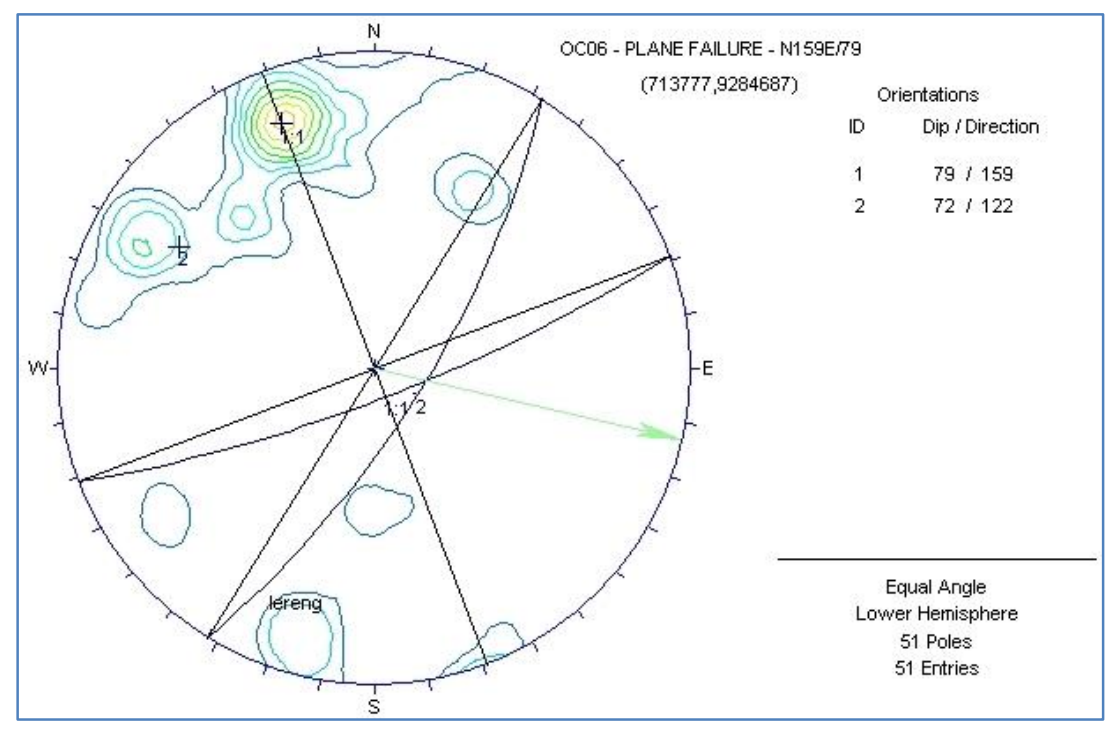

Gambar 11. Analisis stereonet OC6

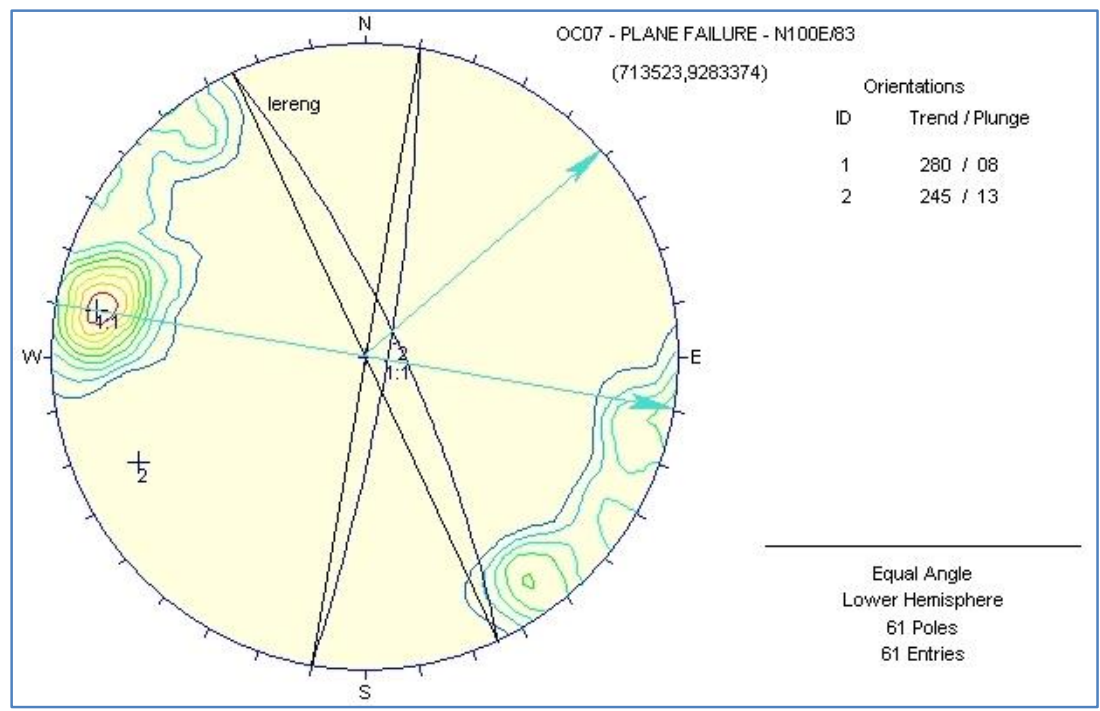

Gambar 12. Analisis stereonet OC7 


\section{Titik Pengamatan OC8}

Strike/dip bidang kekar dan crack pada batuan di titik OC08 berdasarkan pengukuran orientasi di lapangan adalah $\mathrm{NO}^{\circ} \mathrm{E} / 79^{\circ}$. Tipe longsoran yang berpotensi terjadi adalah tipe longsoran bidang (plane failure) pada arah $\mathrm{N} 90^{\circ} \mathrm{E} / 79^{\circ}$. Interpretasi adanya potensi longsoran tipe bidang dapat didasarkan pada keberadaan arah orientasi utama bidang lemah minor (joint set), yaitu pada kekar 1, dengan orientasi garis plunge / trend yaitu $11^{\circ} / \mathrm{N} 270^{\circ} \mathrm{E}$ (Gambar 13) tetapi karena lerengnya lebih landai $\left(72^{\circ}\right)$ maka kecil kemungkinan terjadi longsor.

\section{Titik Pengamatan OC9}

Arah utama dari strike/dip joint dan crack pada batuan berdasarkan pengukuran orientasinya di lapangan adalah $\mathrm{N} 342^{\circ} \mathrm{E} / 76^{\circ}$. Karena hanya dalam satu arah maka kemungkinan tipe longsoran yang berpotensi terjadi adalah tipe longsoran bidang (plane failure). Interpretasi adanya potensi longsoran tipe baji dapat didasarkan pada keberadaan arah orientasi utama bidang diskontinuitas struktur minor (joint set), yaitu pada arah kekar 1 $\left(\mathrm{N} 342^{\circ} \mathrm{E} / 76^{\circ}\right)$, dengan orientasi garis plunge/trend yaitu $14^{\circ} / \mathrm{N} 252^{\circ} \mathrm{E}$ (Gambar 14). Bidang lemah searah dengan bidang lereng
$\left(\mathrm{N} 352^{\circ} \mathrm{E} / 78^{\circ}\right)$ dan sudutnya lebih kecil dibanding sudut kemiringan lereng sehingga terdapat potensi terjadinya longsor.

Secara umum, arah struktur minor batuan yang ada di lokasi pengamatan menunjukkan pada beberapa arah tertentu tetapi terdapat tendensi bahwa arah dominan adalah pada kwadran 4 dan 2 yaitu pada arah Barat Laut - Tenggara dan sebagan kecil berarah Barat Daya - Timur Laut. Hal ini sesuai dengan teori mengenai deformasi yang terjadi di Pulau Jawa pada akhir Kala Miosen Akhir yang sangat berperan dalam pembentukan struktur geologi di daerah Cileungsi dan sekitarnya. Hal tersebut dibuktikan oleh terdeformasinya semua satuan batuan yang tersingkap di daerah penelitian. Struktur geologi yang umumnya berkembang antara lain berupa sesar naik dan lipatan yang berarah barat-timur, serta sesar mendatar yang berarah Barat Laut-Tenggara dan Barat DayaTimur Laut. Arah ini tercermin pada arah utama struktur minor kekar (joint) di areal penelitian. Pola tersebut mengindikasikan bahwa deformasi yang terjadi adalah akibat dari tegasan yang berarah Utara-Selatan yang identik dengan arah subduksi Jawa (Rosanawita, 2010) (Gambar 15).



Gambar 13. Analisis stereonet OC8 


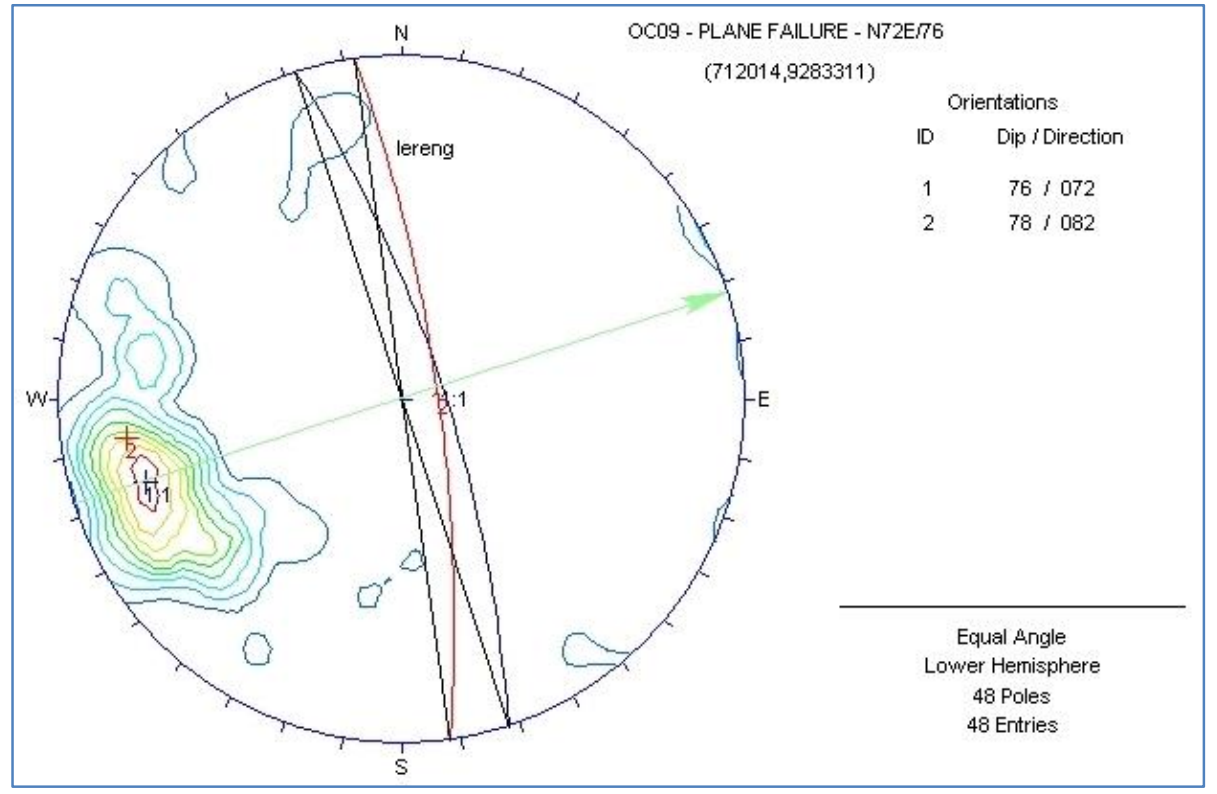

Gambar 14. Analisis stereonet OC9

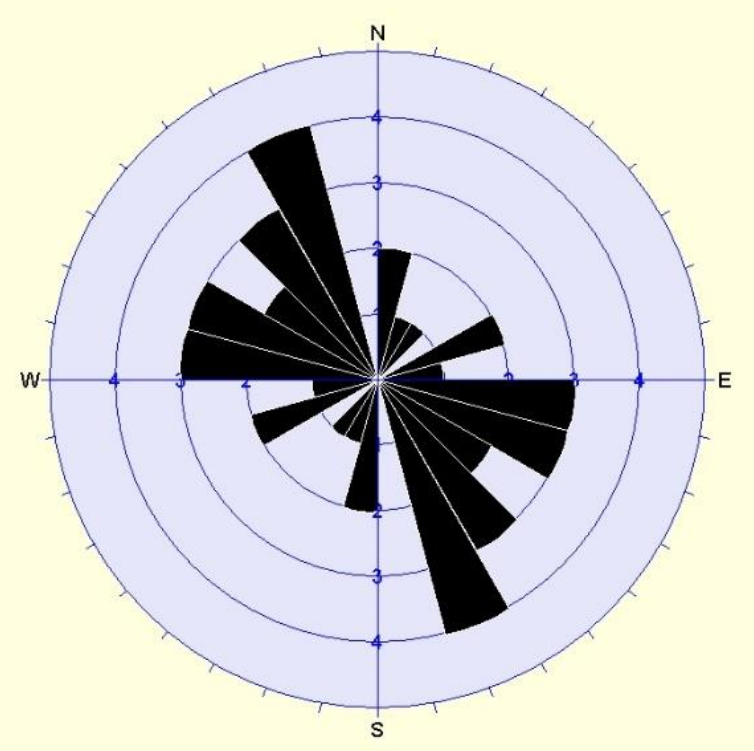

Apparent Strike

5 max planes / arc

at outer circle

Trend / Plunge of

Face Normal $=0,90$

(directed away from viewer)

No Bias Correction

22 Planes Plotted

Within 0 and 90

Degrees of Viewing

Face

Gambar 15. Arah umum struktur minor batuan

\section{KESIMPULAN}

Prediksi hasil analisis kinematik untuk lokasi penelitian menunjukkan potensi longsoran tipe planar ada di 4 lokasi sedangkan potensi longsoran tipe baji ada di 5 lokasi sehingga kemungkinan terjadinya longsor dalam hubungannya dengan searah arah lereng dan kemiringan lebih kecil daripada kemiringan lereng berpotensi terjadi pada 4 titik pengamatan yaitu: ST-03, ST-03d, OC-06, OC09 sedangkan di titik lainnya diperkirakan aman karena tidak searah dengan bidang lereng. Selain itu, arah kekar tidak menunjukkan ke suatu arah dominan tertentu namun ada tendensi bahwa arah dominan adalah pada kwadran 2 dan 4 sehingga desain lereng harus disesuaikan dengan arah utama bidang lemah di setiap lokasi pengamatan. 


\section{UCAPAN TERIMA KASIH}

Penulis mengucapkan terimakasih kepada Puslitbang Teknologi Mineral dan Batubara dan juga pihak lain yang telah memberikan kesempatan untuk membagikan pengetahuan dan keahlian ke dalam tulisan ini.

\section{DAFTAR PUSTAKA}

Abadi, M., Idrus, A. dan Irawan, I. G. B. I. B. (2018) "Kajian geoteknik untuk desain pit tambang batugamping di daerah Karang Dawa, Kecamatan Margasari, Kabupaten Tegal, Jawa Tengah," PROMINE, 6(2), hal. 5-15. doi: $10.33019 /$ promine.v6i2.778.

Atiiqah, F. dan Heriyadi, B. (2020) "Analisis kestabilan lereng front IV pit limit di area penambangan batu kapur PT. Semen Padang Sumatera Barat," Jurnal Bina Tambang, 5(3), hal. 29-38.

Bieniawski, Z. T. (1976) "Rock mass classification in rock engineering," in Bieniawski, Z. T. (ed.) Proceedings of The Symposium on Exploration for Rock Engineering. Balkema: AA Balkema, hal. 97-106.

Brown, E. T. (1981) Rock characterization testing and monitoring: ISRM suggested methods. Pergamon Press.

Deere, D. U., Hendron, A. J., Patton, F. D. dan Cording, E. J. (1967) "Design of surface and near-surface construction in rock," in Fairhurst, C. (ed.) Failure and Breakage of Rock. 1st ed. New York: Society of Mining Engineers of ALME, hal. 237-302.

Deere, D. U. dan Deere, D. W. (1989) Rock quality designation (RQD) after 20 years. Washington: US Army Corps of Engineers.

Effendi, A. C., Kusnama dan Hermanto, B. (1998) "Peta geologi lembar Bogor." Bandung: Pusat Penelitian dan Pengembangan Geologi, hal. 1.

Goodman, R. E. (1989) Introduction to rock mechanics. 2nd ed. Wiley.

Grelle, G., Revellino, P., Donnarumma, A. dan Guadagno, F. M. (2011) "Bedding control on landslides: a methodological approach for computer-aided mapping analysis," Natural Hazards and Earth System Sciences, 11(5), hal. 1395-1409. doi: 10.5194/nhess-11-13952011.
Gurocak, Z., Alemdag, S. dan Zaman, M. M. (2008) "Rock slope stability and excavatability assessment of rocks at the Kapikaya dam site, Turkey," Engineering Geology, 96(1-2), hal. 17-27. doi: 10.1016/j.enggeo.2007.08.005.

Hidayatullah, A. F., Maryanto dan Hirnawan, F. (2018) "Karakteristik geoteknika sebagai dasar penentuan geometri lereng bukaan tambang pada quarry batu gamping di daerah Songgom Kabupaten Brebes Provinsi Jawa Tengah," Prosiding Teknik Pertambangan, 4(1), hal. 203-2013.

Hoek, E. (2007) "Rock mass classification," in Partical Rock Engineering. North Vancouver, hal. 1-23.

Hoek, E. dan Bray, J. (1981) Rock slope engineering. 3rd Ed. Institution of Mining and Metallurgy.

Idris, S. R., Muslim, D., Sulaksana, N. dan Burhannudinnur, M. (2019) "Karakteristik kestabilan lereng daerah Jatigede Kabupaten Sumedang, Provinsi Jawa Barat berdasarkan analisis kinematik," Jurnal Teknologi Mineral dan Batubara, 15(2), hal. 89-96. doi: 10.30556/jtmb.Vol15.No2.2019.1009.

Jariah, D. A., Luthfia, I., Puspita S, N. D., Syam, M. R., Frindy R, D., Hamdah, H., Kamsir, N. P., Rahman, M. F., Maesalangi, W., Massinai, M. A. dan Massinai, M. F. I. (2019) "Penentuan arah tegasan pembentuk kekar menggunakan diagram Rosette (Studi kasus daerah Pattongtongan, Sulawesi Selatan)," Jurnal Geosaintek, 5(1), hal. 13. doi: 10.12962/j25023659.v5i1.4925.

Lee, C.-Y. dan Wang, I.-T. (2011) "Analysis of highway slope failure by an application of the stereographic projection," International Journal of Geological and Environmental Engineering, 5(3), hal. 122-129.

Muntaha, M. (2016) "Studi kestabilan lereng alam tambang terbuka (Studi kasus: lereng tambang batu kapur Lamongan dan Madura)," Jurnal Aplikasi Teknik Sipil, 14(1), hal. 1. doi: 10.12962/j2579-891X.v14i1.3041.

Murniati, R. T., Purwoko, B. dan Syafrianto, M. K. (2020) "Analisis kestabilan lereng pada tambang quarry di PT. Total Optimal Prakarsa (TOP), Desa Peniraman, Kalimantan Barat," JeLAST: Jurnal elektronik Laut, Sipil, Tambang, 7(3), hal. 1-6.

Nurachman, A. G., Najib dan Trisnawati, D. (2017) Analisis kestabilan lereng untuk menentukan desain geometri lereng final pada kuari 
batugamping PT. Semen Indonesia (Persero) Tbk. Tuban, Jawa Timur. Universitas Diponegoro.

Priest, S. D. (1993) Discontinuity Analysis for Rock Engineering. Dordrecht: Springer Netherlands. doi: 10.1007/978-94-011-1498-1.

Rizqi, F. S. (2013) "Analisa struktur geologi," in Buku Praktikum Geologi Struktur, Laboratorium Geologi Dinamis. Bandung: Institut Teknologi Bandung, hal. 93-127.

Rosanawita, P. (2010) Geologi dan analisis struktur geologi daerah Cileungsi dan sekitarnya, Kabupaten Bogor, Jawa Barat. Institut Teknologi Bandung.

Rusydy, I., Sugiyanto, D., Satrio, L., Zulfahriza, . dan Munandar, I. (2016) "Geological aspect of slope failure and mitigation approach in Bireun - Takengon Main Road, Aceh Province, Indonesia," Aceh International Journal of Science and Technology, 5(1), hal. 30-37. doi: 10.13170/aijst.5.1.3841.

Sismiani, A. (2017) "Karakteristik batu gamping dan nilai faktor keamanan pada lereng kuaridi Desa Temandang Kecamatan Merakurak Kabupaten Tuban Jawa Timur," Techno, 18(1), hal. 42-49.

Sophian, I., Herlinawati, Khairullah, N., Abdurrokhim, Haryanto, I. dan Hendarmawan (2019) "Preliminary geomechanical analysis on limestones in PPSDM Geominerba campus, Padalarang, West Java," Indonesian Mining Journal, 22(1), hal. 39-47. doi: 10.30556/imj.Vol22.No1.2019.985.
Sukartono (2013) Buku panduan praktikum geologi struktur. Yogyakarta: Sekolah Tinggi Teknologi Nasional.

Turkandi, T. (1992) "Peta Geologi Lembar Jakarta dan Kepulauan Seribu." Bandung: Pusat Penelitian dan Pengembangan Geologi, hal. 1.

Utama, P. P., Nusantara, Y. P., Aprilia, F. dan Indrawan, I. G. B. (2014) "Analisis kinematika kestabilan lereng batupasir Formasi Butak," in Prosiding Seminar Nasional Kebumian Ke-7. Yogyakarta: Universitas Gadjah Mada, hal. 242-253.

Wibowo, I. J. (2016) Analisis kestabilan lereng di kuari batu andesit CV. Andika Karya Hargorejo Kokap Kulon Progo Yogyakarta. Universitas Pembangunan Nasional "Veteran."

Wijaya, R. A. E. dan Isnawan, D. (2015) "Analisis kekuatan massa batugamping dengan menggunakan kaidah Hoek-Brown failure criterion-roclabdi daerah Gunung Sudo Kabupaten Gunung Kidul Yogyakarta," Jurnal Promine, 3(1), hal. 21-35.

Wijaya, R. A. E., Karnawati, D. dan Srijono, W. W. (2015) "Desain tambang kuari batugamping berongga di Blok Sawir Tuban Jawa Timur," Jurnal Promine, 3(2), hal. 10-17.

Wyllie, D. C. dan Mah, C. W. (2004) Rock slope engineering: Civil and mining. 4th ed. London and New York: Spon Press. 
